\title{
Increase of Lymphocytes with Fc Receptors for IgE in Patients with Allergic Rhinitis during the Grass Pollen Season
}

\author{
Hans L. Spiegelberg and Ronald A. Simon, Department of Immunopathology \\ and Division of Allergy and Immunology, Scripps Clinic and \\ Research Foundation, La Jolla, California 92037
}

\begin{abstract}
A B S T R A C T Peripheral blood lymphocytes from 10 nonallergic donors and 7 patients suffering from seasonal allergic rhinitis and receiving desensitization therapy were analyzed by rosette assays for $\mathrm{F}_{\mathrm{c}}$ receptors for IgE $(F c \in R)$ and $\operatorname{IgG}\left(F_{c} \gamma R\right)$ before, during and after the grass pollen season. Six of seven patients had moderately elevated IgE levels $(330 \pm 268 \mathrm{IU} / \mathrm{ml})$, all had high titers of skin sensitizing antibodies to grass pollens and serum IgE antibodies as measured by radioallergosorbent tests (RAST). Seven of the nonallergic donors had 2-30 IU/ml IgE and negative RAST, whereas three had 91-267 IU/ml IgE and two were RAST positive to the grass pollens. In March, when the patients were asymptomatic, the mean $\pm S D$ of the $\mathbf{F}_{c} \in \mathbf{R}^{+}$lymphocytes did not significantly differ from the nonallergic control group: nonallergic $F \subset \in \mathrm{R}^{+}$ $1.2 \pm 0.9 \%\left(29 \pm 20 / \mathrm{mm}^{3}\right)$, allergic $\mathrm{F}_{\mathrm{c} \in \mathrm{R}^{+}} 2.0 \pm 3.1 \%$ $\left(48 \pm 52 / \mathrm{mm}^{3}\right)$. In contrast, during the grass pollen season in May and June, when the patients developed symptoms of allergic rhinitis, they had significantly $(P<0.01)$ more $\mathrm{Fc}_{\epsilon} \mathrm{R}^{+}$lymphocytes than the controls: nonallergic $F_{c} \epsilon R^{+} 1.7 \pm 1.9 \%\left(40 \pm 46 / \mathrm{mm}^{3}\right)$, allergic $\mathrm{Fc}_{\mathrm{c} \in \mathrm{R}^{+}} 4.7 \pm 1.2 \%\left(134 \pm 69 / \mathrm{mm}^{3}\right)$. In the postpollen period, August-October, most of the patients again had low numbers of $\mathrm{F}_{c} \in \mathrm{R}^{+}$lymphocytes: nonallergic $\mathrm{F}_{\mathrm{c}} \in \mathrm{R}^{+}$ $1.4 \pm 0.9 \% \quad\left(26 \pm 13 / \mathrm{mm}^{3}\right)$, allergic $\mathrm{F}_{\mathrm{c} \in \mathrm{R}^{+}} 2.1 \pm 1.9 \%$ $\left(62 \pm 82 / \mathrm{mm}^{3}\right)$. The nonallergic control donors with elevated IgE levels and positive RAST always had low numbers of $F_{c} \in R^{+}$lymphocytes. In contrast, two other
\end{abstract}

Portions of this work were presented at the Annual Meeting of the American Academy of Allergy, San Francisco, March 1981. This is publication no. 2445 from Scripps Clinic and Research Foundation, La Jolla, California.

Address reprint request to Dr. H. L. Spiegelberg, Department of Immunopathology, Scripps Clinic and Research Foundation, La Jolla, California 92037.

Received for publication 9 April 1981 and in revised form 24 June 1981. nonallergic donors, who had 2-7 IU/ml IgE and negative RAST, showed significant increases of $F c \in R^{+}$ lymphocytes over several weeks during the grass pollen season. No statistically significant changes in $\mathrm{F}_{\mathrm{c}} \mathrm{R}^{+}$ lymphocytes occurred in both nonallergic and allergic donors. The total and specific IgE serum levels did not vary much in the nonallergic donors and patients during the period of study and any changes that did occur did not correlate with the changes in $F_{c \in} R^{+}$lymphocytes.

The data demonstrate that $\mathrm{Fc}_{c} \in \mathrm{R}^{+}$peripheral blood lymphocytes increase in allergic patients during natural antigen exposure and active disease in the absence of measurable increases of total and specific serum IgE. Because two nonallergic control donors also had temporary increases of $F c \in R^{+}$lymphocytes, an increase of peripheral blood $F_{c} \in R^{+}$lymphocytes may be a sensitive indicator of an ongoing $\operatorname{IgE}$ immune response.

\section{INTRODUCTION}

Subpopulations of lymphocytes bear membrane receptors that specifically bind the $\mathrm{Fc}$ fragment of a given immunoglobulin class. Lymphocytes with $\mathrm{Fc}$ receptors for IgG $\left(F_{c} \gamma R\right)^{1}$ have been known for many years (1). Recently, we described a lymphocyte subpopulation that expresses $F_{c}$ receptors for $\operatorname{IgE}\left(F_{c} \in R\right)(2,3)$. The Fc $\epsilon$ receptors on lymphocytes differ antigenically from those on mast cells (4) and bind IgE with an $\sim$ hundredfold lower affinity $(5,6)$. The $F_{c} \in \mathrm{R}^{+}$lymphocytes in normal persons are predominantly $B$ cells that lack $F_{c} \gamma$ receptors (2). Ragweed sensitive donors also have a small fraction of $F c \in R^{+} T$ cells (7). In a previous study (8), we showed that severely atopic patients with highly elevated IgE levels have significantly more $F_{c} \epsilon R^{+}$

${ }^{1}$ Abbreviations used in this paper: $\mathrm{E}$, sheep erythrocytes; Eo, Eo', fresh, fixed ox erythrocytes; FceR, FcyR, Fc $\alpha$ R, Fc receptors for IgE, IgG, and IgA; RAST, radioallergosorbent test; sIg, cell membrane bound immunoglobulin. 
lymphocytes than nonallergic controls. In contrast, allergic patients with moderately high IgE levels and no active disease had essentially the same number of these cells as the controls. To determine whether these patients show an increase of $F_{c} \in \mathrm{R}^{+}$lymphocytes during active disease, we analyzed peripheral blood lymphocytes from patients known to suffer from severe seasonal allergic rhinitis before, during, and after the grass pollen season. We then compared the changes in the percentages of $F c \epsilon \mathrm{R}^{+}$cells with the changes in the patient's total serum IgE and specific IgE as measured by radioallergosorbent test (RAST) to three common grass pollens to which they demonstrated skin sensitizing antibodies.

\section{METHODS}

Subjects. Controls were 10 healthy laboratory or clerical workers who had no history of allergies and had taken no medication at the time of blood testing. Donor 9 was also studied in March 1979 when she had severe generalized contact dermatitis, presumably because of exposure to an unidentified chemical.

12 patients who had a history of severe seasonal allergic rhinitis and were receiving maintenance immunotherapy with weekly subcutaneous injections $(0.5 \mathrm{ml}$ of a $1: 20 \mathrm{wt} / \mathrm{vol}$ grass pollen mixture) volunteered to donate blood for the study. They were chosen because the immunotherapy did not control the hay fever symptoms. All but one of the 12 patients had low percentages of $F_{c \in R^{+}}$lymphocytes on initial examination. Serial blood samples before (March), during (May and June), and after (August through October) the 1980 grass pollen season were obtained from only seven patients. Five of them (1, 2, 4, 6 and 7) had received maintenance immunotherapy for $1 \mathrm{yr}$, patient 3 for $4 \mathrm{yr}$, and 5 for $5 \mathrm{yr}$. Pollen counts were determined daily by Donald Street, University of California at San Diego, School of Medicine, by utilizing the intermittent rotorod method. The mean grass pollen counts per month (spores $/ \mathrm{m}^{3}$ ) were March 1980 3.0, April 8.3, May 12.2, August 1.04, and September 1.02. The seven patients studied demonstrated high titers of skin sensitizing antibodies to grass pollens with $6-10 \mathrm{~mm}$ dermal wheal responses at $1: 10^{-5}$ to $1: 10^{-6}$ dilution of multiple grass pollen antigens. In addition to maintenance immunotherapy, patients were taking oral antihistamines and decongestants and patient 2 also topical nasal beclomethasone throughout the study, particularly when they had severe allergic rhinitis. None of the patients received systemic corticosteroid therapy.

Lymphocytes. Lymphocytes were isolated from $20 \mathrm{ml}$ heparinized venous blood by a slightly modified method originally described by Perlmann et al. (2, 9). Briefly, the erythrocytes were sedimented in $3 \%$ dextran; the mononuclear cell-rich plasma was incubated with colloidal iron, and the iron removed with a magnet. The lymphocytes were then isolated by centrifugation over Ficoll-Hypaque. $<1 \%$ of the cells in these preparations stained for nonspecific esterase (10). For rosette assays, the lymphocytes were suspended at $5 \times 10^{6}$ cells $/ \mathrm{ml}$ in RPMI 1640 medium containing $2.5 \%$ fetal calf serum.

Rosette assays. $\mathrm{F}_{\mathrm{c} \in \mathrm{R}^{+}}$lymphocytes were detected in a rosette assay using fixed ox erythrocytes $\left(\mathrm{Eo}^{\prime}\right)$ coated with human IgE myeloma protein (P. Sha) (2). The rosette assays were performed in duplicate, in the presence and absence of $2 \mathrm{mg} / \mathrm{ml} \mathrm{IgE}$ myeloma protein as inhibitor. The percentage of "spontaneously" formed rosettes which were not inhibit- able with IgE, usually $<0.3 \%$, was subtracted from the number of rosettes formed without inhibitor. Fc $\gamma \mathrm{R}^{+}$lymphocytes were detected in a rosette assay using fresh ox erythrocytes (Eo) sensitized with a subagglutinating dose of rabbit IgG anti-Eo antibodies $(2,11)$. Cell surface IgM and IgD positive lymphocytes $\left(\operatorname{sIgM}^{+}, \operatorname{sIgD}^{+}\right)$were detected with Eo sensitized with conjugates consisting of rabbit Fab' anti-Eo coupled with glutaraldehyde to purified goat $\mathrm{F}\left(\mathrm{ab}^{\prime}\right)_{2}$ antibodies to human IgM or IgD (12). T cells were detected as lymphocytes forming spontaneous rosettes with sheep erythrocytes (E) (12). At least 300 , usually 400-800, lymphocytes were counted to obtain the percentages of rosetting cells. Values $<0.125 \%$ are recorded as $0.0 \%$ in the Tables. Many donors were tested repeatedly within a 2 -wk period before, during, and after the pollen season. Because no significant changes were found in such short time periods, the results were averaged for the data given in the Tables. The data were analyzed statistically with a Student's $t$ test. $P$ values above 0.05 were not considered statistically significant.

IgE determination. Total serum IgE was determined by paper radioimmunosorbent test (PRIST ${ }^{\mathrm{R}}$, Pharmacia, Inc., Piscataway, N. J.) and specific IgE to Timothy, Bermuda, and June grass pollen extract by RAST $^{\mathrm{R}}$ performed by the reference laboratory of Pharmacia, Inc. The serum samples were stored at $-20^{\circ} \mathrm{C}$ and analyzed at the end of the study.

\section{RESULTS}

Fc $\epsilon R^{+}$lymphocytes in nonallergic and allergic donors. The percentages and total numbers of $F_{c} \in \mathrm{R}^{+}$ lymphocytes of 10 nonallergic controls and 7 allergic patients before, during, and after the 1980 grass pollen season are summarized in Table I. In the prepollen season, all donors had low percentages of $\mathrm{Fc} \in \mathrm{R}^{+}$lymphocytes, except for one asymptomatic allergic patient who had $8.7 \%$. The variation from $0-2.7 \%$ in the control donors was not considered significant, because it was occasionally observed in an individual donor tested repeatedly within a 2-wk span. By contrast, 2 of 10 nonallergic donors and 6 of 7 patients had significant increases of $F_{c} \in \mathrm{R}^{+}$lymphocytes during the grass pollen season that clearly exceeded the variations of control donors 1 and 5 who showed the highest variations (Table II). During the pollen season, the mean \pm SD percentage and total number of $F_{c} \epsilon R^{+}$lymphocytes of the patients were significantly higher $(P<0.01)$ than those of the 10 control donors. After the pollen season, one patient still had a high percentage and two a high total number of $\mathrm{F}_{\mathrm{c} \in \mathrm{R}^{+}}$lymphocytes, whereas the others had low numbers of $\mathbf{F} c \in \mathbf{R}^{+}$cells. The two control donors, 9 and 10, who had elevated $\mathrm{F}_{\mathrm{c} \in \mathrm{R}^{+}}$cells during the grass pollen season, had again low numbers of $F c \in R^{+}$ cells in the postpollen season. The $F c \in \mathrm{R}^{+}$cells were repeatedly tested in patient 2 who had $8.7 \% \mathrm{Fc}_{c} \mathrm{R}^{+}$cells in March; they steadily declined over the study period (Table I).

Control donor 9, a 24-year-old female, had previously been serving as a control donor. She had 0.3-1.9\% $\mathrm{F}_{\mathrm{c} \epsilon \mathrm{R}^{+}}$lymphocytes twice in August 1978 and three 
TABLE I

Fc $\epsilon^{+}$Lymphocytes of 10 Nonallergic and 7 Allergic Donors before, during and after the 1980 Grass Pollen Season

\begin{tabular}{|c|c|c|c|c|c|c|c|}
\hline & \multirow[t]{2}{*}{ Age/Sex } & \multicolumn{2}{|c|}{ Prepollen $F_{c \in R^{+}}$} & \multicolumn{2}{|c|}{ Pollen Fce $R^{+}$} & \multicolumn{2}{|c|}{ Postpollen $F_{c \in R^{+}}$} \\
\hline & & $\%$ & per $m^{3}$ & $\%$ & per $m^{3}$ & $\%$ & per $m^{3}$ \\
\hline \multicolumn{8}{|c|}{ Nonallergic donor } \\
\hline 1 (H.S.) & $47 \mathrm{M}$ & 2.7 & 70 & 1.3 & 29 & 0.5 & 13 \\
\hline 2 (P.S.) & $39 \mathrm{~F}$ & 0.7 & 26 & 0.0 & 0 & 1.3 & 29 \\
\hline 3 (G.B.) & $38 \mathrm{M}$ & 1.0 & 20 & 1.6 & 33 & 1.5 & 27 \\
\hline 4 (E.B.) & $38 \mathrm{M}$ & 1.3 & 22 & 0.4 & 5 & 2.0 & 34 \\
\hline 5 (C.B.) & $28 \mathrm{~F}$ & 3.7 & 78 & 1.2 & 23 & 2.8 & 33 \\
\hline 6 (M.S.) & $50 \mathrm{~F}$ & 0.7 & 20 & 1.0 & 32 & 2.5 & 52 \\
\hline 7 (W.G.) & $28 \mathrm{M}$ & 0.8 & 22 & 1.0 & 7 & 2.0 & 30 \\
\hline 8 (S.H.) & $32 \mathrm{~F}$ & 0.3 & 18 & 0.5 & 17 & 0.5 & 19 \\
\hline 9 (T.K.) & $24 \mathrm{~F}$ & 1.4 & 38 & 5.8 & 142 & 0.6 & 15 \\
\hline 10 (S.G.) & $28 \mathrm{M}$ & 0.0 & 0 & 4.6 & 101 & 0.6 & 8 \\
\hline Mean $\pm S D$ & & $1.2 \pm 0.9$ & $29 \pm 20$ & $1.7 \pm 1.9$ & $40 \pm 46$ & $1.4 \pm 0.9$ & $26 \pm 13$ \\
\hline \multicolumn{8}{|c|}{ Allergic patient } \\
\hline 1 ( J.J.) & $63 \mathrm{M}$ & 0.5 & 12 & 5.0 & 92 & 2.8 & 35 \\
\hline 2 (M.S.) & $38 \mathrm{M}$ & 8.7 & 130 & 4.6 & 71 & 1.1 & 17 \\
\hline 3 (J.C.) & $31 \mathrm{M}$ & 1.5 & 55 & 4.3 & 87 & 0.7 & 14 \\
\hline 4 (C.B.) & $33 \mathrm{M}$ & 1.7 & 102 & 6.7 & 207 & 5.8 & 232 \\
\hline 5 (C.W.) & $42 \mathrm{~F}$ & 1.6 & 40 & 2.7 & 71 & 2.8 & 108 \\
\hline 6 (G.G.) & $42 \mathrm{~F}$ & 0.0 & 0 & 4.3 & 223 & 0.9 & 15 \\
\hline 7 (R.M.) & $32 \mathrm{M}$ & 0.0 & 0 & 5.3 & 189 & 0.5 & 10 \\
\hline Mean $\pm S D$ & & $2.0 \pm 3.1$ & $48 \pm 52$ & $4.7 \pm 1.2^{*}$ & $134 \pm 69^{*}$ & $2.1 \pm 1.9$ & $62 \pm 82$ \\
\hline
\end{tabular}

$* P<0.01$.

times in February 1979. She was tested for lymphocyte subpopulations in March 1979 when she had severe systemic contact dermatitis (Fig. 1). At the height of the disease, she had a marked decrease of $E$ rosetting $T$ cells from 78 to $33 \%$, and an increase of $\mathrm{sIgM}^{+} \mathrm{B}$ cells from 6 to $37 \%$ and of $\operatorname{sIgD}^{+} \mathrm{B}$ cells from 8 to $31 \%$. In contrast, neither the percentages nor the absolute numbers of $\mathrm{Fc}_{\mathrm{c}} \mathrm{R}^{+}$and $\mathrm{Fc}_{\mathrm{c}} \mathrm{R}^{+}$lymphocytes changed significantly from values before and after the episode of contact dermatitis. The absolute number of lymphocytes varied from $2,800 / \mathrm{mm}^{3}$ to $3,400 / \mathrm{mm}^{3}$ over the study period, indicating that the change of the $T: B$ cell ratio occurred also in the total number of cells. The B cells were atypical in that most of them did not express FcyR.

Total and specific IgE serum levels in normal donors and allergic patients. The total serum IgE levels and RAST scores (counts per minute) to Timothy, Bermuda, and June grass for the 10 nonallergic donors and 7 allergic patients is shown in Table III. Seven of the control donors had low IgE levels $(2-30 \mathrm{IU} / \mathrm{ml})$ and negative RAST scores $(<1000 \mathrm{cpm})$. Unexpectedly, three control donors $(3,4,8)$ had elevated IgE levels and donors 3 and 4 also had positive RAST scores to all three grass pollens tested. None of these control donors had a history of allergies; in particular, they never had symptoms suggestive of allergic rhinitis and itching or atopic dermatitis resulting from contact with grasses. Normal donors 9 and 10, who had elevated Fce $\mathrm{R}^{+}$lymphocytes during the grass pollen season, both had low IgE levels and negative RAST scores. Donor 9 was skin test negative and donor 10 was skin test positive at a $1: 10^{-3}$ grass pollen dilution. Neither the total IgE nor RAST scores changed much in the nonallergic controls during the study period.

As shown in Table III, six of seven patients had moderately elevated IgE levels and all had positive RAST scores, usually to all three grass pollens. The changes in total IgE and RAST scores during the study period were minor and did not correlate with the changes in the percentages of $F c \in R^{+}$lymphocytes, except for patient 2 , who showed a concomitant decline in $\mathbf{F c} \in \mathrm{R}^{+}$lymphocytes and RAST scores during the study period.

$\mathrm{Fc \gamma R}^{+}$and sIg $^{+}$cells in nonallergic donors and allergic patients. The lymphocytes of all normal donors and all patients were also analyzed for $\mathrm{Fc}_{\mathrm{c}} \mathrm{R}^{+}$ lymphocytes and cell membrane bound immunoglobulin $\left(\mathrm{sIg}^{+}\right)$B cells. As shown in Table IV, no statistically significant differences in the mean $\pm S D$ of $\mathrm{F}_{\mathrm{c}} \mathrm{R}^{+}$lymphocytes and $\mathrm{B}$ cells were observed between nonallergic donors and patients before, during, and after the grass pollen season. However, the pa- 
TABLE II

Percent FceR $\mathrm{R}^{+}, \mathrm{Fc \gamma R}^{+}$and sIg+ Lymphocytes in Nonallergic Donors 9, 10, 1 and 5

\begin{tabular}{|c|c|c|c|c|c|}
\hline \multirow[t]{2}{*}{ Donor } & \multirow[t]{2}{*}{ Date } & \multicolumn{2}{|c|}{$\mathbf{F} \in \mathbf{R}^{+}$} & \multirow{2}{*}{$\frac{\mathrm{FcyR}^{+}}{\%}$} & \multirow{2}{*}{$\frac{\text { sIg }^{+}}{\%}$} \\
\hline & & $\%$ & per $m^{3}$ & & \\
\hline \multirow{7}{*}{9 (T.K.) } & $3 / 20$ & 1.4 & 38 & 11.0 & 16.7 \\
\hline & $5 / 6$ & 6.5 & 121 & 14.0 & 19.8 \\
\hline & $5 / 9$ & 5.2 & 90 & 25.3 & 21.3 \\
\hline & $5 / 14$ & 5.0 & 215 & 13.0 & 9.0 \\
\hline & $6 / 13$ & 2.0 & 85 & 14.7 & 11.0 \\
\hline & $6 / 18$ & 1.6 & 42 & 22.6 & 13.2 \\
\hline & $8 / 7$ & 0.0 & 0 & 11.3 & 4.5 \\
\hline \multirow[t]{7}{*}{10 (S.G.) } & $4 / 1$ & 0.0 & 0 & 31.2 & 8.0 \\
\hline & $5 / 8$ & 3.4 & 91 & 23.0 & 17.3 \\
\hline & $5 / 19$ & 5.5 & 139 & 30.3 & 13.0 \\
\hline & $5 / 27$ & 5.0 & 75 & 33.7 & 12.2 \\
\hline & $6 / 12$ & 3.7 & 102 & 37.7 & 18.8 \\
\hline & $8 / 20$ & 0.6 & 8 & 14.6 & 7.0 \\
\hline & $9 / 19$ & 2.7 & 40 & 13.0 & 11.5 \\
\hline \multirow{4}{*}{1 (H.S.) } & $3 / 19$ & 2.3 & 64 & 8.6 & 4.3 \\
\hline & $3 / 24$ & 3.1 & 78 & 10.3 & 3.0 \\
\hline & $5 / 1$ & 1.3 & 29 & 9.5 & 3.6 \\
\hline & $8 / 13$ & 0.5 & 13 & 8.5 & 5.0 \\
\hline \multirow[t]{5}{*}{5 (C.B.) } & $3 / 25$ & 3.1 & 78 & 6.3 & 8.8 \\
\hline & $4 / 2$ & 2.3 & 27 & 16.0 & 6.3 \\
\hline & $5 / 7$ & 1.2 & 23 & 15.3 & 10.3 \\
\hline & $6 / 18$ & 0.8 & 35 & 16.6 & 16.3 \\
\hline & $8 / 20$ & 2.8 & 33 & 6.8 & 11.7 \\
\hline
\end{tabular}

tients showed the lowest percentages of $\mathrm{Fc}_{\mathrm{c}} \mathrm{R}^{+}$cells at the time when their percentages of $F c \in \mathrm{R}^{+}$cells were increased during the grass pollen season, perhaps because a portion of the $F c \gamma R^{+}$cells became $F c \in R^{+}$cells. We have previously shown that lymphocytes are either $\mathrm{F}_{c} \gamma \mathrm{R}^{+}$or $\mathrm{F}_{\mathrm{c} \epsilon} \mathrm{R}^{+}$, but rarely both (2).

\section{DISCUSSION}

The subpopulation of $\mathrm{Fc}_{\mathrm{C}} \mathrm{R}^{+}$peripheral blood lymphocytes increases in atopic patients sensitive to the grass pollens when they are exposed to antigen and have allergic rhinitis. The increase of $F_{c \in} R^{+}$lymphocytes was not associated with significant increases of total serum IgE or specific IgE, as determined by RAST to Bermuda, Timothy, and June grass pollens. Most patients showed relatively small changes in total and specific serum IgE levels and, except for one patient (2), the changes that did occur did not correlate with the changes in $\mathbf{F} c \in \mathbf{R}^{+}$lymphocytes. In a previous study, we showed that mildly atopic patients with moderately elevated IgE levels had normal numbers of $F c \in R^{+}$lymphocytes, whereas severely atopic patients with IgE levels $>10,000 \mathrm{IU} / \mathrm{ml}$ had elevated percentages of $\mathrm{Fc}_{\mathrm{i}} \mathrm{R}^{+}$lymphocytes. We had assumed that the very high levels of IgE were responsible for the large numbers of $\mathrm{F}_{\mathrm{C}} \in \mathrm{R}^{+}$lymphocytes. However, the present observations indicate that mildly atopic patients with moderately increased IgE levels also have high percentages of $F c \in R^{+}$lymphocytes when they are exposed to antigen and have active allergic disease.

The increase of $F c \in R^{+}$cells appears to correlate with exposure to antigen rather than allergic disease; in fact, it may be an indicator of an ongoing IgE response. Two healthy nonallergic donors showed significant increases of $F c \in R^{+}$lymphocytes during the grass pollen season. The two nonallergic donors had no history of allergic disease, low IgE levels and negative RAST; one was skin test negative to grass pollens and the other only moderately positive. The increase of $F c \in R^{+}$ lymphocytes may be unrelated to an IgE response in these donors. However, this seems unlikely in view of the finding of Yodoi and Ishizaka (7) demonstrating that $\mathbf{F} c \in \mathrm{R}^{+}$lymphocytes increase in rats during an IgE response resulting from infection with the parasite Nippostrongylus brasiliensis. Since immunoglobulin serum levels do not change appreciably during normally occurring immune responses, both donors may have had small IgE responses at the time of the in-
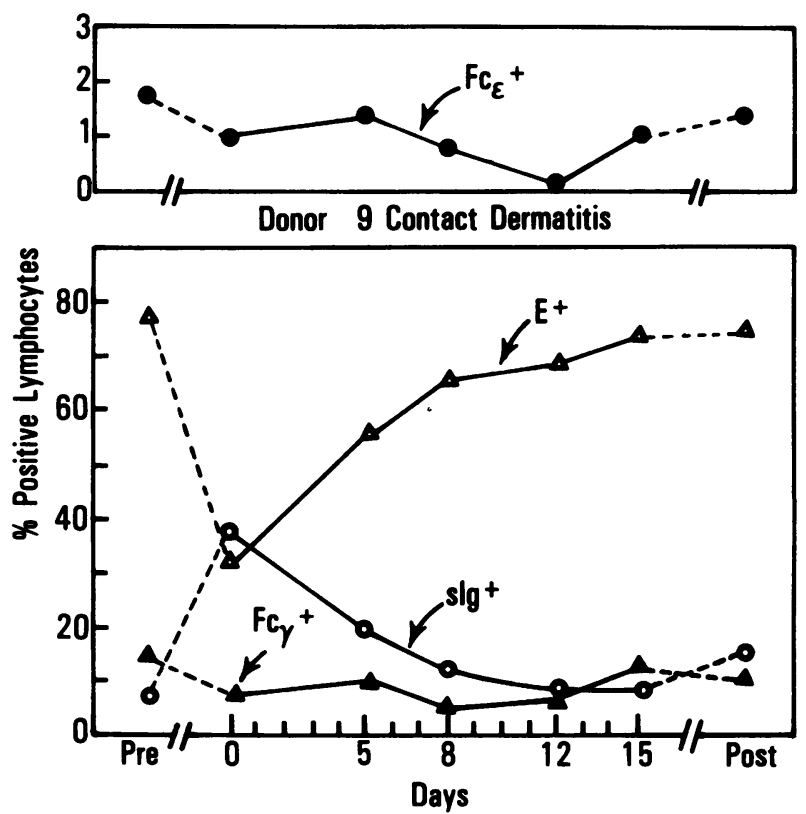

FIGURE 1 Lymphocyte subpopulations of nonallergic donor 9 during generalized contact dermatitis (day 0 to day 15). $\mathrm{E}^{+}=\mathrm{T}$ cells forming spontaneous rosettes with sheep erythrocytes; $\mathbf{s I g}^{+}=\mathrm{sIgM}^{+} / \mathrm{sIgD}^{+}$cells; $\mathrm{Fc}^{+}, \mathrm{Fc \epsilon}^{+}=$lymphocytes forming rosettes with rabbit IgG or human IgE coated ox red cells. Pre, Post $=$ values obtained $\sim 1$ mo before or after the contact dermatitis. 
TABLE III

IgE Serum Concentrations and RAST Scores to Timothy, Bermuda and June Grass Pollen of 10 Nonallergic Donors and 7 Allergic Patients before, during and after the 1980 Grass Pollen Season

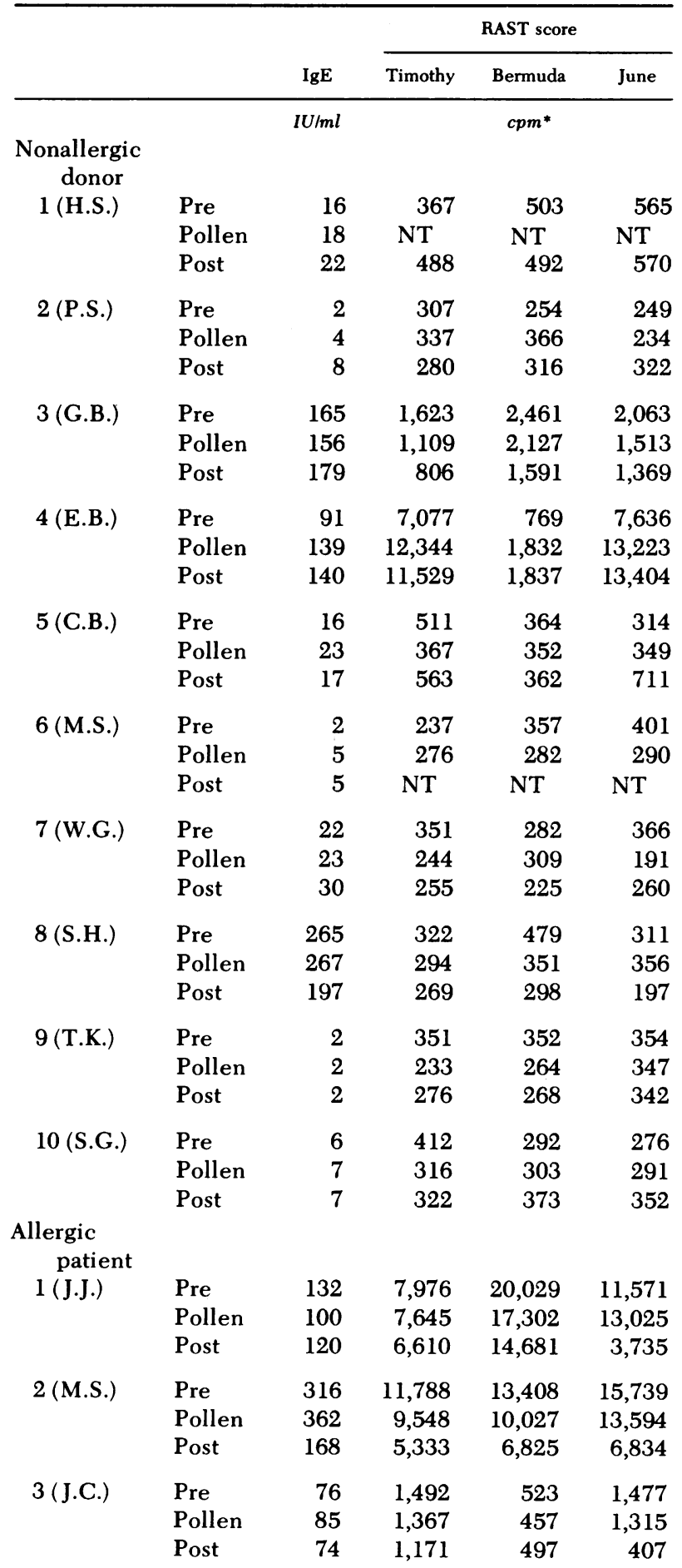

TABLE III (Continued)

\begin{tabular}{|c|c|c|c|c|c|}
\hline & & \multirow[b]{2}{*}{ IgE } & \multicolumn{3}{|c|}{ RAST score } \\
\hline & & & Timothy & Bermuda & June \\
\hline & & $I U / m l$ & & cts/min* & \\
\hline \multirow[t]{3}{*}{4 (C.B.) } & Pre & 375 & 1,213 & 2,953 & 1,233 \\
\hline & Pollen & 301 & 1,062 & 3,375 & 992 \\
\hline & Post & 241 & 1,135 & 3,811 & 824 \\
\hline \multirow[t]{3}{*}{5 (C.W.) } & Pre & 880 & 23,814 & 17,197 & 27,554 \\
\hline & Pollen & 969 & 24,614 & 18,031 & 27,691 \\
\hline & Post & 1,350 & 24,493 & 18,548 & 29,633 \\
\hline \multirow[t]{3}{*}{6 (G.G.) } & Pre & 192 & 13,197 & 10,295 & 16,660 \\
\hline & Pollen & 163 & 13,960 & 9,842 & 16,579 \\
\hline & Post & 130 & 13,230 & 9,571 & 14,766 \\
\hline \multirow[t]{3}{*}{7 (R.M.) } & Pre & 323 & 23,634 & 27,659 & 28,685 \\
\hline & Pollen & 389 & 21,968 & 25,157 & 27,957 \\
\hline & Post & 468 & 26,087 & 28,118 & 29,434 \\
\hline
\end{tabular}

$*<1,000 \mathrm{cpm}$ is considered negative. NT, not tested.

crease of $\mathrm{F}_{\mathrm{c} \epsilon \mathrm{R}^{+}}$lymphocytes. Whether they made IgE antibodies to grass pollens in amounts too small for detection by RAST, or whether they responded to another antigen, is unknown. We will study these two donors during future grass pollen seasons to determine whether their increases of $\mathbf{F c} \in \mathbf{R}^{+}$lymphocytes were related to the grass pollen season or simply coincidental. Assuming that the increase of $F c \in \mathrm{R}^{+}$lymphocytes is an indication of IgE antibody formation, the observations made in the two nonallergic donors indicate that an increase of $F c \in R^{+}$lymphocytes is not restricted to atopic individuals and can occur in the absence of allergic symptoms and high IgE serum levels.

Most of the allergic patients did not show a significant rise in total IgE during the grass pollen season. This is consistent with previous reports demonstrating that patients receiving immunotherapy do not show the increase of $\operatorname{IgE}$ seen in untreated hay fever patients $(13,14)$. The lack of an increase in specific IgE as measured by RAST during the grass pollen season may also have been the result of immunotherapy. Patients receiving long term maintenance immunotherapy usually have high titers of IgG blocking antibody that may be responsible for falsely low IgE RAST scores $(15,16)$. It is likely that our patients made at least a small IgE response when they were exposed to the grass pollens. Therefore, enumerating $F c \in R^{+}$lymphocytes may prove to be the more sensitive indicator of an IgE host response than measuring total or specific IgE serum levels.

The mechanism of generation of $F c \in R^{+}$lymphocytes is not understood. In man, an increase of the IgE serum 
TABLE IV

$\mathrm{Fc}_{c} \mathrm{R}^{+}$and sIg ${ }^{+}$Lymphocytes in Nonallergic and Allergic Donors before, during and after the Grass Pollen Season

\begin{tabular}{cccc}
\hline & Prepollen & Pollen & Postpollen \\
\cline { 2 - 3 } & & $\mathrm{F}_{\mathrm{c}} \mathrm{R}^{*}$ & \\
\hline
\end{tabular}

\begin{tabular}{lllc} 
Nonallergic (10) & $15.7 \pm 7.8$ & $18.0 \pm 8.1$ & $14.8 \pm 7.5$ \\
Allergic (7) & $17.6 \pm 12.6$ & $11.9 \pm 6.9 \ddagger$ & $14.4 \pm 4.7$ \\
& & & \\
& & $\% s^{+}$ & \\
Nonallergic (10) & $10.2 \pm 4.7$ & $11.6 \pm 4.2$ & $8.3 \pm 3.0$ \\
Allergic (7) & $12.4 \pm 6.4$ & $12.8 \pm 5.4$ & $9.9 \pm 4.2$ \\
\hline
\end{tabular}

* Mean \pm SD

$\downarrow 0.3>0.2$

level per se, does not appear to cause an increase of Fc $\epsilon \mathrm{R}^{+}$lymphocytes. The atopic donors had higher IgE levels than the nonallergic controls but only slightly higher numbers of $F_{c} \in R^{+}$cells before and after the grass pollen season. Three nonallergic donors also had elevated IgE levels, yet their numbers of $F c \in R^{+}$lymphocytes were always low. Previously, we injected two monkeys with an IgE myeloma protein; neither developed an increase of $F c \in R^{+}$cells despite their high levels of circulating IgE (8). Similarly, culturing lymphocytes from normal (6) or allergic patients (17) in the presence of IgE did not induce $\mathrm{Fc}_{\mathrm{c}} \mathrm{R}^{+}$cells. In contrast, $\mathrm{F}_{\mathrm{c} \in \mathrm{R}^{+}}$ cells formed when lymphocytes from ragweed sensitive patients were cultured with both ragweed antigen $\mathrm{E}$ and an IgE myeloma protein (17). Furthermore, lymphocytes activated by mixed lymphocyte culturing became $\mathrm{Fc}_{\mathrm{c}} \mathrm{R}^{+}$when $\operatorname{IgE}$ was added to the culture medium (18). These in vitro studies suggest that the generation of $F_{c} \in \mathrm{R}^{+}$lymphocytes may first involve activation of the cells and then modulation by IgE. The activation may result from antigen exposure or from interaction of the lymphocytes with accessory cells such as macrophages. IgE secreted in the microenvironment of the lymphocytes may then modulate the activated cells to express $F_{c \in} R$.

In contrast to human cells, rat lymphocytes become $\mathrm{FceR}^{+}$-bearing cells when the IgE concentration increases in the cells' environment. Yodoi and Ishizaka $(18,19)$ demonstrated that culturing normal rat mesenteric lymph node lymphocytes in the presence of $\mathrm{IgE}$ induces generation of $F c \in R^{+}$cells. We injected purified IgE myeloma proteins into normal rats which resulted in an increase of $F_{c \in R} R^{+}$lymphocytes in the blood, spleen and nodes. ${ }^{2}$ These in vitro and in vivo obser-

\footnotetext{
${ }^{2}$ Spiegelberg, H. L. Manuscript in preparation.
}

vations do not necessarily indicate that $\mathrm{Fc}_{\mathrm{C}} \mathrm{R}^{+}$lymphocytes are generated via a different mechanism in rats and humans. As discussed above, the generation of Fce $\mathrm{R}^{+}$lymphocytes may initially involve a cell activation step after which IgE modulates the activated cell. Rats may have a more responsive IgE system than humans, since rats normally have higher proportions of $\mathrm{F}_{\mathrm{c} \in \mathrm{R}^{+}}$lymphocytes in their blood and spleen (20) than man (3). This higher value for $F c \in R^{+}$cells may reflect a larger percentage of activated lymphocytes, which become induced to form Fce receptors by the normally low concentrations of IgE.

Lymphocytes with $F_{c}$ receptors for $\operatorname{IgA}\left(F_{c} \alpha R\right)$ are increased in mice bearing IgA secreting plasmacytomas (21) and patients with IgG or IgA multiple myeloma also have increases in $F_{c} \gamma R^{+}$or $F c \alpha R^{+}$lymphocytes, respectively (22). The IgA serum concentrations in normal individuals are much higher than those of $\operatorname{IgE}$; however, the subpopulation of $F c \alpha R^{+}$lymphocytes is numerically similar to the $F c \in \mathrm{R}^{+}$subpopulation (23). Most likely, the serum concentrations of all immunoglobulin classes influence the number of the respective Fc receptor-positive lymphocytes, yet the threshold concentrations necessary to induce $\mathrm{Fc}$ receptor positive cells appear to be different.

One of the nonallergic control donors was studied at the time when she had severe, generalized, contact dermatitis. She showed a marked increase in the percentage and total number of $\operatorname{sIg}^{+} B$ cells and a decrease of $\mathrm{E}$ rosetting $\mathrm{T}$ cells, particularly at the height of disease. In contrast, her percentage and total numbers of $F_{c \in} R^{+}$and $F c \gamma R^{+}$lymphocytes remained within normal limits. Contact dermatitis is believed to be a $\mathrm{T}$ lymphocyte-mediated, delayed hypersensitivity reaction, and a decrease of $T$ cells has also been reported by others (24). It was reported that patients with contact dermatitis have an increase of $\operatorname{sIgD}^{+}$but not $\operatorname{sigM}{ }^{+}$ lymphocytes (25). Our donor had a high number of both $\mathrm{sIgD}^{+}$and $\mathrm{sIgM}^{+}$lymphocytes, suggesting that she had an increase of $\mathrm{sIgM}^{+} / \mathrm{sIgD}^{+}$peripheral blood B lymphocytes, which neither expressed Fc $\epsilon$ nor Fc $\gamma R$. The majority of $F c \in R^{+}$lymphocytes in normal donors $(2,3)$ and in atopic patients $(7,8)$ are $B$ cells. The fact that the numbers of lymphocytes with Fce receptors remained normal in the donor during the acute contact dermatitis, despite the overall B cell increase, supports our assumption that an increase of $F c \in R^{+}$cells is most likely related to an IgE immune response and does not represent some nonspecific phenomenon.

The function of the Fce receptors on lymphocytes is unknown. The significantly larger population of $\mathbf{F} c \in \mathbf{R}^{+}$lymphocytes in allergic patients and in rats infected with $N$. brasiliensis parasites (7), conditions associated with IgE responses, suggests that Fc $\epsilon$ receptors may play a regulatory role by either enhancing or 
suppressing IgE antibody formation. Evidence was obtained suggesting that interactions between IgE antibody-antigen complexes and $\mathrm{Fc}_{\mathrm{c}} \mathrm{R}^{+} \mathrm{B}$ cells inhibit the differentiation of B cells into plasma cells (26-29). Analogously, IgE antibody-antigen complexes may react with $\mathrm{F}_{c} \in \mathrm{R}^{+} \mathrm{B}$ cells and prevent them from differentiating into $\operatorname{sgE}^{+}$lymphocytes and subsequently into IgE producing plasma cells. Rat $\mathrm{T}$ lymphocytes with $F_{c \epsilon}$ receptors were recently identified as the source of IgE binding factors which, depending on their state of glycosylation, have either a potentiating or suppressing effect on the in vitro generation of $\operatorname{IgE}$ forming cells (30-32). These IgE binding factors may be $F_{c \epsilon}$ receptors or Fc $\epsilon$ receptor fragments released from the cells. Although both the clinical and the experimental observations strongly suggest that Fce receptors on $B$ and $T$ lymphocytes are involved in the regulation of $\operatorname{IgE}$ antibody formation, their definitive role remains to be shown.

\section{ACKNOWLEDGMENTS}

The authors thank Ms. Gloria Portillo and Ms. Patricia Stuart for excellent technical, Mrs. Phyllis Minick for editorial, and Mrs. Margaret Stone for secretarial assistance.

This study was supported by U. S. Public Health Service grant AI-10734, Allergy Center grant AI-10386, and Biomedical Research Support Program grants RRO-5514 and RRO-0833.

\section{REFERENCES}

1. Dickler, H. B. 1976. Lymphocyte receptors for immunoglobulin. Adv. Immunol. 24: 167-207.

2. Gonzalez-Molina, A., and H. L. Spiegelberg. 1977. A subpopulation of normal human peripheral B lymphocytes that bind IgE. J. Clin. Invest. 59: 616-624.

3. Hellström, U., and H. L. Spiegelberg. 1979. Characterization of human lymphocytes bearing $F_{c}$ receptors for IgE isolated from blood and lymphoid organs. Scand. J. Immunol. 9: 75-86.

4. Meinke, G. C., A. M. Magro, D. A. Lawrence, and H. L. Spiegelberg. 1978. Characterization of an IgE receptor isolated from cultured B-type lymphoblastoid cells. $J$. Immunol. 121: 1321-1328.

5. Ishizaka, T. 1980. IgE receptors and their interference. In Adv. Allergology and Clin. Immunol. A. Ochling, I. Glazer, E. Methor and C. Arkesman, editors. Pergamon Press, Inc., New York. 586-588.

6. Spiegelberg, H. L., and F. M. Melewicz. 1980. Fc receptors for $\operatorname{IgE}$ on subpopulations of human lymphocytes and monocytes. Clin. Immunol. Immunopathol. 15: 424-433.

7. Yodoi, J., and K. Ishizaka. 1979. Lymphocytes bearing Fc receptors for IgE. I. Presence of human and rat T lymphocytes with Fce receptors. J. Immunol. 122: 2577-2583.

8. Spiegelberg, H. L., R. D. O’Connor, R. A. Simon, and D. A. Mathison. 1979. Lymphocytes with immunoglobulin E Fc receptors in patients with atopic disorders. J. Clin Invest. 64: $714-720$.
9. Perlmann, H., P. Perlmann, G. R. Pape, and G. Hallden. 1976. Purification, fractionation, and assay of antibodydependent lymphocyte effector cells ( $\mathrm{K}$ cells) in human blood. Scand. J. Immunol. 5(Suppl.): 57-68.

10. Horwitz, D. A., A. C. Allison, P. Ward, and N. Knight. 1977. Identification of human mononuclear leucocyte populations by esterase staining. Clin. Exp. Immunol. 30: 289-298.

11. Hallberg, T., B. W. Gurner, and R. R. A. Coombs. 1973. Opsonic adherence of sensitized ox red cells to human lymphocytes as measured by rosette formation. Int. Arch. Allergy Appl. Immunol. 44: 500-513.

12. Spiegelberg, H. L., and P. M. Dainer. 1979. Fc receptors for IgG, IgM, and IgE on human leukemic lymphocytes. Clin. Exp. Immunol. 35: 286-295.

13. Levy, D. A., L. M. Lichtenstein, E. O. Goldstein, and K. Ishizaka. 1971. Immunologic and cellular changes accompanying the therapy of pollen allergy. J. Clin. Invest. 50: 360-369.

14. Gleich, G. J., G. L. Jacob, J. W. Yuninger, and L. L. Henderson. 1977. Measurement of the absolute levels of IgE antibodies in patients with ragweed hay fever. J. Allergy Clin. Immunol. 60: 188-198.

15. Zeiss, C. R., L. C. Grammer, and O. Levitz. 1981. Comparison of the radioallergosorbent test and a quantitative solid phase radioimmunoassay for the detection of ragweed specific immunoglobulin $\mathrm{E}$ antibody in patients undergoing immunotherapy. J. Allergy Clin. Immunol. 67: $105-110$.

16. Zimmerman, E. M., J. W. Yuninger, and G. J. Gleich. 1980. Interference in ragweed pollen and honeybee venom radioallergosorbent tests. J. Allergy Clin. Immunol. 66: 386-393.

17. Yodoi, J., and K. Ishizaka. 1980. Induction of Fce-receptor bearing cells in vitro in human peripheral lymphocytes. J. Immunol. 124: 934-938.

18. Yodoi, J., T. Ishizaka, and K. Ishizaka. 1979. Lymphocytes bearing $F_{C}$ receptors for IgE. II. Induction of $F_{c} \epsilon-$ receptor bearing rat lymphocytes by IgE. J. Immunol. 123: 455-462.

19. Yodoi, J., and K. Ishizaka. 1979. Lymphocytes bearing receptors for IgE. III. Transition of $\mathrm{F}(\gamma \mathrm{R}(+)$ cells to $F_{c \in R}(+)$ cells by IgE. J. Immunol. 123: 2004-2010.

20. Fritsche, R., and H. L. Spiegelberg. 1978. Fc receptors for IgE on normal rat lymphocytes. J. Immunol. 121: 471-478.

21. Hoover, R. G., and R. G. Lynch. 1980. Lymphocyte surface membrane immunoglobulin in myeloma. II. T cells with $\mathrm{IgA}-\mathrm{Fc}_{\mathrm{c}}$ receptors are markedly increased in mice with IgA plasmacytoma. J. Immunol. 125: 1280-1285.

22. Hoover, R. G., S. Hickman, H. M. Gebel, N. Rebbe, and R. G. Lynch. 1981. Expansion of $F_{c}$ receptor-bearing $T$ lymphocytes in patients with immunoglobulin $G$ and immunoglobulin A myeloma.J. Clin. Invest. 67: 308-311.

23. Lum, L. G., A. V. Muchmore, N. O'Connor, W. Strober, and R. M. Blaese. 1979. Fc receptors for IgA on human B and human non-B non-T lymphocytes. J. Immunol. 123: 714-719.

24. Carpeto, F. J., R. K. Winkelmann, and R. E. Jordon. 1976. $\mathrm{T}$ and $\mathrm{B}$ lymphocytes in contact and atopic dermatitis. Arch. Dermatol. 112: 1095-1100.

25. Cormane, R. H., S. Husz, and F. Hamerlinck. 1974. Immunoglobulin-complement-bearing lymphocytes in allergic contact dermatitis and atopic dermatitis (eczema). Br. J. Dermatol. 90: 597-605. 
26. Sinclair, N. R. St. C. 1969. Regulation of the immune response. I. Reduction in ability of specific antibody to inhibit long-lasting IgG immunological priming after removal of the Fc fragment. J. Exp. Med. 129: 1183-1201.

27. Ryan, J. L., R. D. Arbeit, H. B. Dickler, and P. A. Henkart. 1975. Inhibition of lymphocyte mitogenesis by immobilized antigen-antibody complexes. J. Exp. Med. 142: 814-826.

28. Sidman, C. L., and E. R. Unanue. 1976. Control of $\beta$-lymphocyte function. I. Inactivation of mitogenesis by interaction with surface immunoglobulin and Fc-receptor molecules. J. Exp. Med. 144: 882-896.

29. Kölsch, E., J. Oberbarnscheidt, K. Brüner, and J. Heuer.
1980. The Fc-receptor: its role in the transmission of differentiation signals. Immunol. Rev. 49: 61-78.

30. Yodoi, J., and K. Ishizaka. 1980. Lymphocytes bearing Fc receptors for IgE. IV. Formation of IgE-binding factor by rat T lymphocytes. J. Immunol. 124: 1322-1329.

31. Suemura, M., J. Yodoi, M. Hirashima, and K. Ishizaka. 1980. Regulatory role of IgE-binding factors from rat T lymphocytes. I. Mechanism of enhancement of IgE response by IgE-potentiating factor. J. Immunol. 125: 148-154.

32. Yodoi, J., M. Hirashima, and K. Ishizaka. 1980. Regulatory role of IgE-binding factors from rat $\mathrm{T}$ lymphocytes. II. Glycoprotein nature and source of IgE-potentiating factor. J. Immunol. 125: 1436-1441. 